\title{
På \\ begge sider av bordet
}

\section{Liv Walseth fikk tilværelsen snudd på hodet da mannen fikk hjerneslag. En filosofisk tilnær- ming til livet og pasientene har hjulpet henne med å finne balansen i etterkant.}

Hun er en erfaren allmennlege, har tatt en medisinskfilosofisk doktorgrad om kommunikasjon med pasienter og er i ferd med å bli psykiater. Først hadde hun ikke så lyst til å bli intervjuet. Så tenkte hun seg om. Hun har noen erfaringer hun syntes var viktige.

Timeplanen er stram, men en lørdag formiddag møter jeg opp ved en hyggelig lysmalt enebolig $i$ en hage full av blomster i Kristiansand. Hun har vokst opp i byen, men har vært lite på sjøen.

- Foreldrene mine var begge lærere, faren min var fra Setesdal og moren min fra Telemark. I absolutt alle ferier gjennom hele oppveksten var vi i Setesdal. Den dagen skolen sluttet, reiste vi til et småbruk der. Vi hadde sauer, tok inn høy og var sammen med slekten. I høstferien tok vi opp poteter. Hun smiler. - Du skjønner tegningen.

- Hvorfor ble du lege?

- Jeg ville bli psykiater, det var derfor jeg begynte på studiet. Jeg hadde vel et ønske om å hjelpe folk.

Hun ler og konkluderer selv med at det var litt naivt. Men først ble det en god del år i allmennpraksis.

\section{Vendepunktet}

Begge barna var tenåringer og bodde hjemme da familien fikk snudd livet på hodet. Mannen fikk et alvorlig hjerneslag.

- Han var på institusjon i et år. Det er lenge, men det var en vel så hard kamp å stå i etterpå når det gjaldt hva slags hjelp han skulle få.

- Hvordan var det å være mottaker av helsetjenester?

- Det har vært både og. Det vanskeligste har vært å få på plass den praktiske hjelpen fra kommunen. Jeg holdt fast på at han måtte ha mer hjelp enn det de så for seg. Her i byen har vi en enhet for behovsprøvde tjenester. Noen sitter på et kontor og bestemmer hva slags type hjelp pasienten skal ha uten å kjenne saken spesielt godt. Det er store forventninger til hva pårørende skal stille opp med. Hjemmesykepleien skulle bare komme innom til faste tidspunkter, mens han var helt hjelpeløs. Jeg holdt fast på at han trengte personlig assistent. De så rart på meg og sa forundret: «Jobber du?» Det var mange forventninger om at jeg ikke skulle stå i arbeid lenger. Pasientene trenger en talsmann ovenfor et slikt system. Det har jeg sett enda tydeligere nå som jeg arbeider $\mathrm{i}$ annenlinjetjenesten.

\section{«Det er lettere å aksep- tere en situasjon hvis legen tydelig aner- kjenner det pasienten opplever»}

Vi kan utrede og konkludere, men når det kommer til de begrensede ressursene kommunen har, møter pasienten en mur. Jeg kjenner jo til det fra allmennpraksis, men jeg så det ikke så tydelig da. Det er noe som mangler i samhandlingsreformen. Man trenger noen som tilser at pasientene får det de har behov for, og krav på. Det kan ikke være slik at det er de som står på, som får mest.

Kampen bar frukter til slutt.

- Til sjuende og sist fikk han personlig assistent og omsorgsbolig, og er hjemme faste dager i uken. Dessuten har vi hatt enorm støtte av nettverket vårt. Tross alt har vi vært heldige.

\section{Rollebytte}

Først hadde Walseth byttet mellom rollen som lege og rollen som pårørende i helsevesenet. Så ble hun selv alvorlig syk.

- De siste brikkene var endelig på plass. Han hadde fått den hjelpen han trengte.
Samme dag gikk det hull på hjernehinnen min. Jeg ble liggende på sykehuset $i$ to måneder og til slutt operert på Rikshospitalet. Det tok tid før man skjønte hva som var problemet, og at det var en sjelden kronisk sykdom som lå bak.

Walseth opplevde hvordan det er å ha uforklarte symptomer.

- Det er vanskelig å feile noe som ingen forstår hva er, samtidig som du står oppe i store påkjenninger. Noen hadde nok lyst til å forklare det med at jeg var veldig sliten. Når man ikke får gjenklang om det man feiler hos andre, er det nesten som om man ikke tror på det selv. Når man ikke møter noe forståelse i blikket, er det som om det man erfarer, ikke eksisterer. Fenomenet interesserte meg før jeg ble syk selv. Medisinsk uforklarte plager, det tomrommet som disse pasientene strever med, var en erfaring å kjenne på før jeg selv ble diagnostisert. - Hvordan kan vi møte dette som leger?

- Her mangler vi kunnskap, men vi må i alle fall gjøre vårt beste for å fylle det tomrommet med forståelse. Det er lettere å akseptere en situasjon hvis legen tydelig anerkjenner det pasienten opplever.

\section{Frisk etikk}

- Du har vært opptatt av salutogenese, hva er det egentlig?

- I motsetning til patogenese, det som gjør oss syke, er salutogenese det som gjør oss friske. Det går an å bruke kunnskap om hva salutogenese er, i samtaler med pasienter hvor målet er å styrke mestring, og hva som tross alt er forståelig og forutsigbart, i stedet for bare å fokusere på hva som ikke fungerer.

- Doktorgraden din handler om hvordan vi skal snakke sammen?

- Interessen for salutogenese førte meg videre til å se på prosessen mot å kunne gjøre gode valg.

Jürgen Habermas har inspirert Liv Walseth. Han er sosiolog og filosof og en av vår tids største tenkere. 


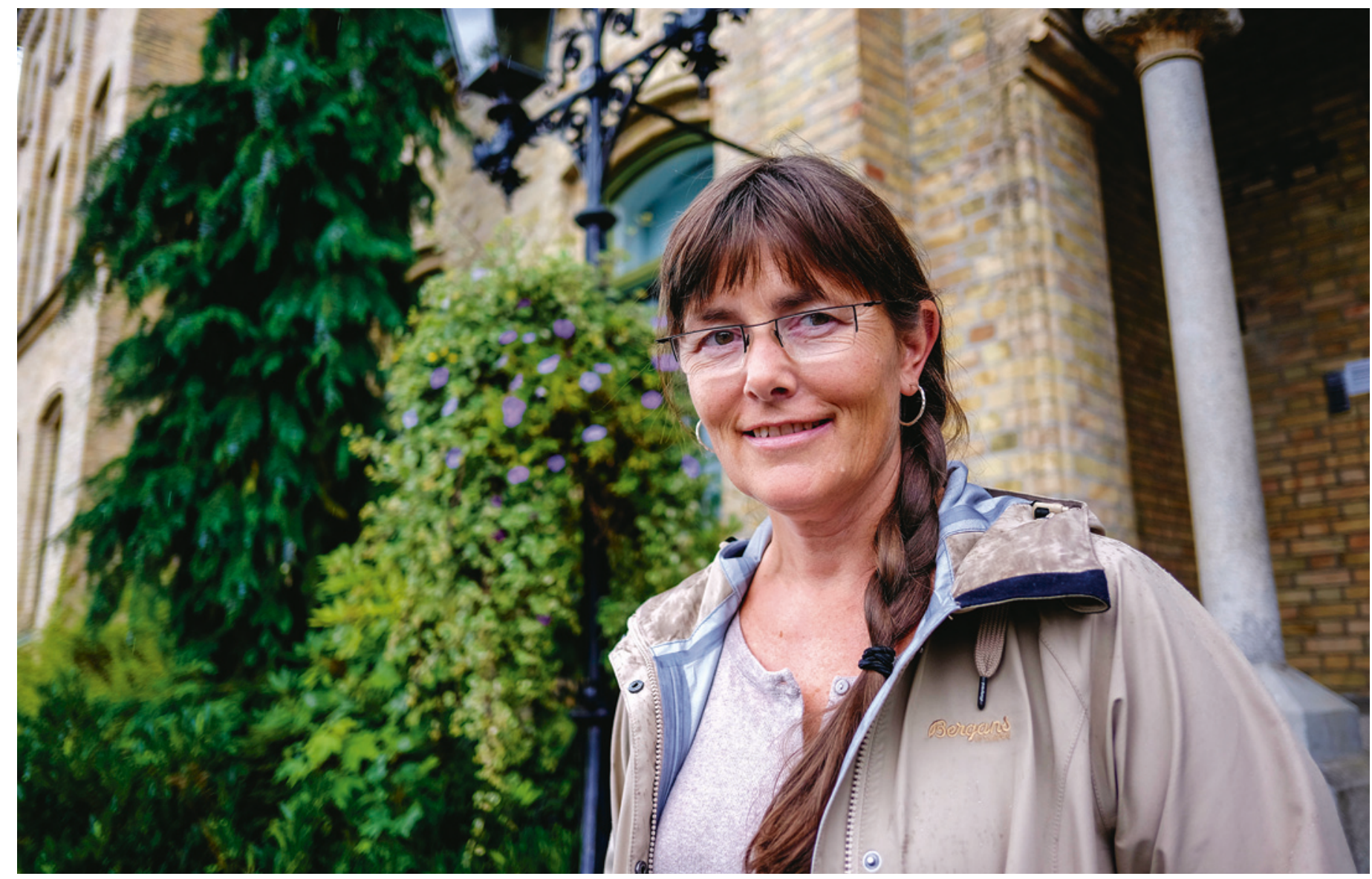

Foto: NTB scanpix

\section{Liv Tveit Walseth}

Født 13. februar 1960

- Cand.med. Universitetet i Trondheim 1984

- Spesialist i allmennmedisin 1995

- Ph.d. Universitetet i Bergen 2012

- Lege i spesialisering i psykiatri ved Sørlandet sykehus
- Han har utviklet teorien om kommunikativ handling. Det handler om prosessen mot å komme frem til beslutninger som er begrunnet $i$ verdier og normer, og at dette er en type fornuft som gir større mulighet for at det som bestemmes, gjennomføres. Teorien var ment til bruk i demokratiske prosesser. Han utviklet dette som en reaksjon mot den modernistiske tankegangen, at det finnes et svar for alt og at systemer kan løse alle problemer. Han hevder at en slik tankegang kan bli helt feil for enkeltmennesker, samtidig som han anerkjenner at det må være systemer. Vi som leger står i spennet mellom systemverden og individverden hele tiden. Vi må forholde oss både til regler for blåresept og til behovene til den enkelte pasient. Doktorgraden min handler om hvordan Habermas' teori kan være relevant for lege-pasient-arbeidet, og viser muligheter for hvordan man kan tenke for å tilstrebe en etisk dialog.

- Hvorfor begynte du å forske på dette som allmennlege?

- Etter 15 år i allmennpraksis begynte jeg å reflektere over måten jeg snakket med pasientene på. Samtalen er vårt viktigste redskap. Jeg fikk lyst til å teoretisere det, løfte meg litt opp, prøve å forstå hva som skjer, og hvordan kvaliteten på samtalen kunne bli bedre. Da jeg begynte å lese filosofi, traff Habermas veldig, forteller hun.

- Det er kanskje en familiesvakhet. Søsteren min har tatt en doktorgrad hvor hun har brukt Habermas' metode som utgangspunkt for foreldresamtaler.

\section{Hverdagsetikk}

- Hvordan vil du forklare hva etisk dialog dreier seg om?

- Det handler om hvordan vi gjennom samtale kan hjelpe pasienten med å trekke inn alle forholdene i livet som er av betydning. Habermas har satt opp hvilket innhold en samtale må ha for at man skal kunne treffe gode beslutninger. Der tar han med både praktiske forhold som gjelder pasientens liv, hva pasienten selv opplever som godt, og hvordan pasienten oppfatter det som riktig å oppføre seg. Hvis alle disse aspektene er inne, og man reflekterer over det, kan det ende i gode beslutninger som lettere virkeliggjør livet man ønsker å leve. - Det høres nesten for enkelt?

- Livet er alt annet enn enkelt. Det har en kompleksitet og uoversiktlighet som vi må ha respekt for. Vi kan aldri få full oversikt, men vi kan tilstrebe å ta hensyn til det 
gode, det rette og det praktiske når vi skal bestemme oss for hva vi skal gjøre. Som leger kan vi reflektere over dette sammen med pasientene.

- Mange vil vel innvende at det ikke går an å ha slike samtaler i hverdagen i helsevesenet?

- Nei, men man kan likevel ha idealer og tilby å være samtalepartnere som går en vei sammen med pasienten mot gode beslutninger. Det handler selvsagt ikke bare om innhold i samtalen, men også om å snakke respektfullt og noe som jeg tror er veldig viktig - en åpenhet om at man kan ta feil. Som leger går det an å være trygg på den medisinske kunnskapen uten å låse seg til løsninger som skal passe alle. Medisin er ikke et matematikkstykke, men noe som skjer i møtet mellom legens kunnskap og pasientens kunnskap. Det vil alltid være unikt. Hvis man tenker slik, tror jeg kanskje pasientene ikke føler seg overkjørt, men at de får være med på en prosess og en beslutning.

\section{Livsstilsråd}

- Du har forsket på hvordan leger skal gi råd om livsstilsendring. Hva skal man si for å få pasienten med på det?

- Hvis man tenker filosofisk på det, kommer pasienten til konsultasjonen med sin livsverden og sine opplevelser. Vi kommer med vår kunnskap. Vi kan vite hva som er sunt, men det er ikke sikkert at det passer inn i pasientens liv. Et eksempel er røykeslutt. Det kan være lett å si at det er skadelig å røyke, men hvis man har satt seg inn i hvordan pasienten har det, er det kanskje ikke det riktige tidspunktet. Man må ha respekt for hva som passer i pasientens liv. - I allmennpraksis skal man forebygge sykdom. Kommer vi til målet?

- Jeg tror det er noe på gang, med frisklivssentraler og gode tilbud.

- Hvordan skal man hjelpe folk med å endre livet sitt?

- Det tror jeg på ingen måte at man skal tenke enkelt om. Jeg tror vi leger har noe å komme med, men vi må gå veien sammen med pasienten. Det er ofte mange brikker som skal falle på plass i en pasients liv. Vi må ha respekt for at det ikke er enkelt, og at det er mye vi ikke vet om hvorfor nettopp denne pasienten for eksempel er overvektig. Vi kan bidra som samtalepartnere. Når det gjelder forebygging, er det jo heller ikke rådgivning på individnivå som er viktigst. De store linjene, med subsidiering av sunne matvarer, større avgifter på usunne saker og tilrettelegging for fysisk aktivitet, er nok det som har størst betydning for folkehelsen.

\section{Balansekunst}

- Nå jobber du som lege i spesialisering. Har du hatt nytte av erfaringen som pasient og pårørende?

- Jeg har større forståelse for hva det innebærer å miste en funksjon. Det å være avhengig av hjelp av andre, hva det gjør

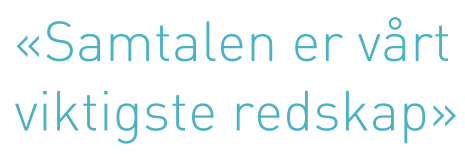

med en, det har jeg større ydmykhet overfor. Løsningen på et funksjonsfall handler ikke bare om å ta seg sammen. Det er så mye snakk om at man kan jobbe med tanker, men noen grenser er det faktisk. Jeg tror nok også jeg uttrykker større forståelse i møtet med symptomer som er vanskelige å forklare, og går kanskje veien med pasientene litt lengre enn før. På psykiatrisk poliklinikk hadde jeg pasienter med diffuse plager, som jeg kanskje brukte mer tid på enn jeg ville gjort før. Jeg tror det har gjort noe med meg å være syk selv. Nei, jeg vet at det har gjort noe med meg, retter Liv.

Venner er imponert over at hun klager lite, til tross for at livet har gitt henne store belastninger.

- Jeg føler ikke at jeg tar alt på strak arm, men det hadde vel ingen gjort. Det har vært tungt, men jeg har ikke gått inn i noen depresjon. Det kunne vært nærliggende fordi livet har vært så dramatisk og krevende de siste årene. Jeg har jo ikke hele forklaringen, men noe av det handler om at jeg har prøvd å være åpen. Da mener jeg åpen både i forhold til å dele hva som skjer, og også være åpen for det gode som folk kommer med. Det hjalp veldig da mannen min ble syk. De første månedene var det usikkert om han overlevde. Venner og familie bare var der. Om det så bare var en melding på telefonen, var det akkurat som snøfnugg som lindret og dekket over det som var så vondt. Men lett har det ikke vært.

- Du har klart deg?

- Jeg har møtt mye vennlighet og fått utrolig mye praktisk hjelp. Det er ikke så lett å ta imot alt sammen, men det har hjulpet oss til å beholde en verdighet. Venner har gjort hagearbeid og hatt med mat når de har kommet på besøk. På jobben har jeg også møtt mye forståelse. Jeg begynte i ny jobb med sykmelding og var nyoperert. Ledelsen var vennlig og forståelsesfull. Nå er livet veldig timet. Vi må planlegge helger lang tid på forhånd sammen med hjemmesykepleien. Det er lite rom for spontanitet, og det er noe jeg savner.

- Hva er helsefremmende for deg?

- Jeg har lært mye gjennom samtaler med pasienter. Jeg har sett hvor viktig det er å holde fast ved noen ting i livet. Vi må ta noen utfordringer, ikke si nei til alt, men samtidig sette gode grenser. Så må vi av og til ta noen sjanser og også gjøre ting som er krevende. Det er det som fungerer for meg. Jeg har måttet hvile mye, men det nytter samtidig ikke bare å kjenne på egen slitenhet. Balanse i livet må man ta vare på. Jeg tror det hjelper å ha en bevissthet rundt det. Jeg er veldig glad $i$ jobben min. I perioder jobbet jeg bare en liten prosent, men jeg kom meg ut om morgenen, fikk nye inntrykk og følelsen av å mestre noe. Det har betydd mye for meg.

\section{Marit Tveito}

Marit.tveito@me.com

Alderspsykiatrisk avdeling

Diakonhjemmet Sykehus 